\title{
APPLICATIONS OF MATHEMATICS CHARGED ISLAMIC VALUES BY USING MACROMEDIA FLASH AND CAMTASIA
}

\author{
Agus Ahmad Durri, Hendri Raharjo and Arif Muchyidin \\ agus_ahmaddurri@yahoo.co.id hendri_rahario@syekhnurjati.ac.id, arif_muchyidin@syekhnurjati.ac.id
}

\author{
Jurusan Tadris Matematika, \\ Fakultas Ilmu Tarbiyah dan Keguruan, \\ Institut Agama Islam Negeri Syekh Nurjati Cirebon, Kota Cirebon
}

\begin{abstract}
Some factors of low interresting of Mathematic learning material for student on Junior High School grade (SMP/MTs) are design of learning material that is less animation and the difficuties of use the learning material. Therefore, the use of learning material should be inovated for increasing the learners' interrest, to make them easy understanding the subject that has been learnt, and still capable to increase reigion value in their ownselves. One form of this effort is to create learning material in the form of flash mathematics with consits Islamic value. Flash application is an application that can be developed in accordance animatif developer creativity. The purpose of the research is the developing of learning material in the electric learning form that consists Islamic value in Transformation subject. The method of research is research and development, and the design of the research is using the steps of ADDIE model, there are analysis, design, development, implemetation, and evaluation. Data collection techniques included interviews and observations with research instruments are questionnaires, observation sheets and tests. Further analysis of the data conducted by researchers consists of qualitative and quantitative analysis to determine the feasibility and effectiveness of the teaching materials developed. The results of the expert evaluation consisting of a material expert and a media expert, shows that the average velue obtained from every aspects: content quality and purpose, instructional quality of learning material, aspects of the charge Islamic value, and the technique quality was 4.37 that very good category. The results of the assessment by the teachers of Junior High School grade (MTs) Nurul Huda Munjul which consist of two Mathematics teacher and a teacher of Information and Communication Technology (ICT), shows that the average velue of each aspect was 4.46 with very good category. Than the student quationnaire responses result data obtained by the average velue of each aspects: the quality of learning and instructional, technical aspects of the display, and payload integrition aspects of Islamic value in learning material, namely 3.98, with good categories. The data test scores of student learning outcomes gained an average of $82.34>K K M$ (75) with the classical completeness of $89.19 \%>85 \%$. The conclusion showed that the quality of Mathematic learning materials charged Islamic velues are developed with macromedia flash and catamsia aplications is feasible and effective to be used in the learning process.
\end{abstract}

Keywords: Learning Material, Flash Multimedia, Islamic Value, Transfromation. 


\section{PENDAHULUAN}

Di era modernisasi saat ini tidak dapat dipungkiri kontribsi multimedia terhadap pendidikan sangat besar dan signifikan, terlebih perkembangan media teknologi yang kian pesat membuat peran media semakin benar-benar dibutuhkan dalam kinerja pembelajaran. Keberadaan multimedia dalam proses pembelajaran dapat disusun dan diarahkan semenarik mungkin. Proses pembelajaran dengan berbasis multimedia merupakan salah satu bentuk upaya peningkatan kualitas pembelajaran, namun perlu diperhatikan keberadaan multimedia tentu harus menjadi fasilitas yang memudahkan siswa memahami materi, bukan justru menghambat pemahaman siswa terhadap materi yang dipelajari. Oleh karena itu, keberadaan multimedia sebagai penunjang efektifitas belajar perlu kualifikasi dan pengembangan yang signifikan sesuai kebutuhan dan pemanfaatan yang diperlukan.

Seorang pendidik disarankan untuk dapat mengembangkan bahan ajar yang akan digunakan dalam proses pembelajaran. Salah satu bentuk pengembangan bahan ajar adalah dengan memanfaatkan multimedia elektronik sehingga pendidik dapat mengembangkan bahan ajar berbasis multimedia yang interaktif dan ekeftif. Akan tetapi, multimedia sebagai penunjang efektifitas belajar tentu harus memiliki muatan pembelajaran nilai-nilai karakter dan religi yang disampaikan dan ditauladankan pendidik kepada para peserta didik sehingga keberadaan bahan ajar berbasis multimedia multimedia tidak semata-mata mengubah sistem pendidikan dengan mesin atau media seperti robot.

MTs Nurul Huda Munjul merupakan salah satu satuan pendidikan berbasis Islam. Keberadaannya tidak lepas dari upaya bersama mencerdaskan anak-anak bangsa yang berjiwa Islami dan berakhlak mulia. Kendati demikian, penerapan nilai-nilai Islam dalam pembelajaran ilmu-ilmu umum masih sulit diaplikasikan. Sebagaimana umumnya problema yang dihadapi tiap-tiap satuan pendidikan berbasis Islam. Sehingga mata pembelajaran ilmu-ilmu umum sering tidak difokuskan lebih dalam karena pembelajaran lebih terkonsentrasi secara khusus pada ilmu-ilmu agama. Selanjutnya pemanfaatan multimedia pembelajaran di kelas masih cenderung monoton penerapannya serta pemberian tampilan multimedia yang masih kurang bervariasi. Padahal di era modern saat ini telah tersedia berbagai aplikasi yang mampu menyajikan media pembelajaran yang dikemas lebih menarik dan animatif.

Salah satu aplikasi yang dapat mendukung pengembangan bahan ajar non-cetak adalah aplikasi macromedia flash professional 8 atau dikenal dengan macromedia flash, aplikasi ini dapat digunakan dalam membuat media pembelajaran yang lebih menarik dan animatif. Selain itu flash juga dapat menampilkan video yang dimuat dari aplikasi lain melalui import video dari menu flash. Sehingga bahan ajar flash dapat dikembangkan dengan mengaitkan berbagai aplikasi yang mendukung pembuatan video. Salah satu aplikasi yang dapat membuat, merekam, dan mengedit video adalah aplikasi camtasia.

Berdasarkan latar belakang masalah di atas, peneliti melakukan penelitian dengan judul "Pengembangan Bahan Ajar Matematika Bermuatan Nilai-nilai Islam dengan Menggunakan Macromedia Flash dan Camtasia pada Pokok Bahasan Transformasi di Kelas VII MTs Nurul Huda Munjul Cirebon”.

\section{KAJIAN PUSTAKA}

a. Deskripsi Teoritik

1. Pengembangan bahan ajar berbasis multimedia

Bahan ajar merupakan segala bentuk materi yang dikemas dalam sebuah bahan atau media baik cetak maupun non-cetak yang membantu efektifitas pembelajaran agar tercipta proses pembelajaran yang interaktif, inovatif, menyenangkan, dan bermanfaat. Menurut Daryanto (2011: 53) karakteristik multimedia pembelajaran adalah: (1) memiliki lebih dari satu media yang konvergen, misalnya menggabungkan unsur audio dan visual; (2) bersifat interaktif, dalam pengertian memiliki kemampuan untuk mengakomodasi respons 
pengguna; dan (3) bersifat mandiri, dalam pengertian memberi kemudahan dan kelengkapan isi sedemikian rupa sehingga pengguna bisa menggunakan tanpa bimbingan orang lain.

Menurut Ariani, dkk (2010: 12) ada beberapa manfaat yang dapat diambil dalam pembelajaran berbasis multimedia, yaitu :

a. Pengenalan perangkat teknologi informasi dan komunikasi kepada siswa.

b. Memberikan pengalaman baru dan menyenangkan baik bagi guru itu sendiri maupun siswa.

c. Mengejar ketertinggalan pengetahuan Iptek dibidang pendidikan.

d. Pemanfaatan multimedia dapat membangkitkan motivasi belajar para pembelajran, karena adanya multimedia membuat presentasi pembelajaran lebih menarik.

e. Multimedia dapat digunakan membantu pembelajaran membentuk model mental yang akan memudahkan memahami suatu konsep.

f. Mengikuti perkembangan Iptek.

2. Aplikasi macromedia flash

Menurut Waryanto (2005: 1) macromedia flash adalah software yang banyak dipakai oleh desainer web karena mempunyai kemampuan yang lebih unggul dalam menampilkan multimedia, gabungan antara grafis, animasi, suara, serta interaktifitas user. Macromedia flash merupakan sebuah program aplikasi standar authoring tool profesional yang digunakan untuk membuat animasi vektor dan bitmap yang sangat menakjubkan untuk membuat suatu situs web yang interaktif, menarik dan dinamis. Software ini berbasis animasi vektor yang dapat digunakan untuk menghasilkan animasi web, presentasi, game, film, maupun CD interaktif, CD pembelajaran.

3. Aplikasi camtasia studio

Aripin (2009: 2) menerangkan bahwa aplikasi Camtasia Studio merupakan perangkat lunak (software) yang dikembangkan oleh Tech Smith Coorporation khusus bidang multimedia. Camtasia Studio adalah program aplikasi yang dikemas untuk recording, editing, dan publishing dalam membuat video presentasi yang ada pada layar (screen) komputer. Camtasia studio adalah software untuk meng-capture tampilan layar monitor dengan ditambahi audio dan video, serta dapat juga kita gunakan untuk merekam hasil presentasi power point ke dalam format video. Camtasia Studio dapat membantu dan melatih kita dalam menyampaikan serta berinteraksi dengan audiens karena aplikasi camtasia studio memiliki kemampuan untuk merekam dan mengedit suara yang ada dalam layar.

4. Nilai-nilai Islam

Mahmud Syaltut juga sebagaimana dikutip oleh Muthahhari (2005: 32), mengungkapkan bahwa nilai-nilai Islam dapat dijabarkan ke dalam tiga aspek utama yaitu nilai akidah atau keyakinan, nilai syariah dan nilai akhlak. Nilai-nilai aqidah mengajarkan manusia untuk percaya akan adanya Allah Yang Maha Esa dan Maha Kuasa sebagai Sang Pencipta alam semesta, yang akan senantiasa mengawasi dan memperhitungkan segala perbuatan manusia di dunia. Dengan merasa sepenuh hati bahwa Allah itu ada dan Maha Kuasa, maka manusia akan lebih taat untuk menjalankan segala sesuatu yang telah diperintahkan oleh Allah dan takut untuk berbuat dzalim atau kerusakan di muka bumi ini. Nilai-nilai syariah atau ibadah mengajarkan pada manusia agar dalam setiap perbuatannya senantiasa dilandasi hati yang ikhlas guna mencapai rido Allah. Pengamalan konsep nilai-nilai ibadah akan melahirkan manusia-manusia yang adil, jujur, dan suka membantu sesamanya. Selanjutnya yang terakhir nilai-nilai akhlak mengajarkan kepada manusia untuk bersikap dan berperilaku yang baik sesuai norma atau adab yang benar dan baik, sehingga akan membawa pada kehidupan manusia yang tenteram, damai, harmonis, dan seimbang. Dengan demikian jelas bahwa nilai-nilai ajaran Islam merupakan nilai-nilai yang dapat diintegrasikan ke dalam proses pembelajaran matematika dan bahan ajar matematika.

b. Tinjauan hasil penelitian yang relevan

Di bawah ini beberapa penelitian yang berkaitan dengan penelitian ini yaitu antara lain sebagai berikut:

1. Penelitian yang telah dilakukan oleh Sholikatun Khasanah pada tahun 2014 yaitu Pengembangan Bahan Ajar Matematika Berbasis Pendidikan Nilai Islam pada Pokok 
Bahasan Himpunan di MTs Negeri Mlinjon Klaten. Dalam penelitian ini, menunjukkan bahwa terdapat kesamaan dengan penelitian yang dilakukan penulis yaitu mengenai bahan ajar yang dikembangkan adalah bermuatan atau berbasis pendidikan nilai-nilai Islam. Adapun perbedaanya bahwa bahan ajar yang dikembangkan dalam penelitiannya adalah bahan ajar cetak sedangkan peneliti sendiri mengembangkan bahan ajar dalam bentuk non-cetak.

2. Penelitian yang telah dilakukan oleh Dessy Kristanto pada tahun 2014 yaitu Pengembangan Media Pembelajaran Interaktif Melalui Media Macromedia Flash pada Materi Peluang di Kelas XI IPS SMA Negeri 1 Purbalingga. Dalam penelitian ini, menunjukkan bahwa terdapat kesamaan dengan penelitian yang dilakukan penulis yaitu mengenai media pembelajaran yang dikembangkan adalah media macromedia flash pada mata pelajaran matematika. Adapun perbedaanya adalah muatan media pembelajaran yang dikembangkan Kristanto tidak terdapat muatan nilai-nilai Islamnya.

c. Kerangka Pemikiran

Pembelajaran di sekolah merupakan aktivitas peningkatan kemampuan kognitif, afektif dan psikomotorik siswa ke arah yang lebih baik. peningkatan pendidikan perlu diupayakan, salah satunya adalah dengan mengembangkan kualitas bahan ajar agar lebih menarik dan mampu meningkatkan antusias, motivasi dan prestasi belajar siswa serta meningkatkan nilai-nilai karakter dan agama pada setiap diri siswa.

Seorang pendidik yang profesional akan terus mengupayakan berbagai metode dan pengembangan bahan ajar yang inovatif, salah satu bahan ajar yang diharapkan menjadi sumber belajar kreatif dan inovatif adalah dengan memanfaatkan media teknologi sebagai upaya meningkatkan efektifitas proses pembelajaran.

Oleh karena itu melalui upaya pengembangan bahan ajar matematika bermuatan nilai-nilai Islam dengan menggunakan macromedia flash dan camtasia diharapkan dapat membantu memudahkan para pendidik dalam menyampaikan pembelajaran matematika dengan tetap menjunjung tinggi nili-nilai Islam dan karakter peserta didik serta diharapkan pula para peserta didik dapat memahami materi ajar lebih mudah, menarik, menyenangkan, efektif dan inovatif mealui bahan ajar berbasis multimedia sehingga kualitas proses pembelajaran kian meningkat dengan ditandai oleh meningkatnya hasil, prestasi, antusias dan pemahaman siswa.

Berdasarkan pemikiran di atas peneliti melakukan pengembangan bahan ajar bermuatan nilai-nilai Islam berbasis multimedia flash yang disertai video pembelajaran. Beberapa tahapan yang dilakuakan antara lain; tahap analisis, tahap perencanaan atau desain, dan tahap pembuatan. Selanjutnya bahan ajar yang telah dikembangkan diuji coba di dalam proses pembelajaran selama beberapa pertemuan yaitu di kelas eksperimen yang telah ditentukan. Kemudian di dalam proses pembelajaran dilakukan observasi kelas dan diakhir pertemuan dilakukan tes hasil belajar dan angket respon siswa. Adapun untuk mengetahui perbedaan hasil belajar antara kelas yang menerapkan bahan ajar yang telah dikembangkan di dalam penelitian ini dengan yang tidak menerapkan bahan ajar maka peneliti juga memberikan tes hasil belajar kepada kelas yang tidak menerapkan bahan ajar yang dikembangkan yaitu pada kelas kontrol.

d. Hipotesis Penelitian

Berdasarkan pada teori-teori dan kerangka pemikiran di atas, maka hipotesis yang diajukan dan diuji kebenarannya adalah bahan ajar matematika bermuatan nilai-nilai Islam yang dikembangkan dengan macromedia flash dan camtasia pada pokok bahasan transformasi efektif digunakan dalam proses pembelajaran matematika.

\section{METODOLOGI}

a. Subyek Penelitian

subyek yang melakukan penelitian dan pengembangan adalah penulis, dosen pembimbing, ahli materi, ahli media, guru mata pelajaran matematika dan guru TIK di MTs Nurul Huda Munjul serta seluruh peserta didik kelas VII di MTs Nurul Huda Munjul Cirebon angkatan tahun pelajaran 2015/2016. Jumlah keseluruhan kelas VII ada 6 kelas yang terdiri atas 220 siswa. Kelas uji coba dalam penelitian ini dilakukan pada dua kelas yaitu kelas VII B dan kelas VII E. Kelas VII B merupakan kelas eksperimen yaitu kelas yang menerapkan bahan 
ajar yang dikembangkan. Adapun kelas VII E adalah kelas kontrol yaitu kelas yang tidak menerapkan bahann ajar yang dikembangkan.

b. Desain Penelitian

Metode penelitian pada dasarnya merupakan cara ilmiah untuk mendapatkan data dengan tujuan dan kegunaan tertentu (Sugiyono, 2009: 2). Penelitian ini merupakan penelitian dan pengembangan berdasarkan metode Research and Development ( $\mathrm{R} \& \mathrm{D}$ ). adapun design yang digunakan adalah design/model pengembangan ADDIE yang terdiri atas lima tahap pengembangan yaitu Analysis, Design, Development, Implement, dan Evaluation. Salah satu fungsi model ADDIE adalah menjadi pedoman dalam mengembangkan suatu produk (Baharuddin, 2012: 221).

c. Langkah-angkah penelitian

1. Analysis (Analisis) meliputi analisis kurikulum, analisis karakteristik peserta didik, analisis materi bahan ajar, dan analisis muatan nilai-nilai islam dalam bahan ajar.

2. Design (Perancangan), Menurut Multiyaningsih (2011: 201) tahap design merupakan tahap untuk merancang produk pengembangan, namun masih bersifat konseptual. Langkah yang dilakukan adalah membuat flowchart dan storyboard secara tertulis, langkah ini meliputi; merencanakan, merancang, menulis dan menyusun tampilan, animasi, gambar, grafik, tombol navigasi, video dan musik dengan menyesuaikan komponen-komponen yang akan dimuat dalam bahan ajar berbasis multimedia flash interaktif, selanjutnya peneliti juga menyusun kerangka instrumen untuk memvalidasi bahan ajar.

3. Development (Pengembangan), tahap pengembangan adalah proses mewujudkan desain penelitian menjadi kenyataan maka yang dilakukan dalam tahap ini adalah memproduksi bahan ajar dengan macromedia flash kemudian membuat video dan audio yang akan dimasukkan ke dalam bahan ajar yang akan dikembangkan dengan aplikasi camtasia yang dikombinasi dengan berbagai aplikasi seperti power point, geogebra, powtoon, sparkol, dll.

4. Implementation (Penerapan), tahap ini adalah melaksanakan program pembelajaran yang telah dibuat dalam bentuk aplikasi multimedia flash pembelajaran bermuatan nilai-nilai Islam dengan menerapkannya pada kegiatan pembelajaran di kelas. Menurut Multiyaningsih (2011: 2020) Tahap evaluasi adalah tahap dimana suatu proses untuk menentukan kualitas dan efektivitas produk akhir. Tahap evaluasi adalah proses untuk melihat apakah bahan ajar yang tengah dikembangkan berhasil dan sesuai dengan harapan awal atau tidak.

\section{HASIL PENELITIAN DAN PEMBAHASAN}

a. Hasil Penelitian

1. Analysis (Analisis)

Analisis yang dilakukan peneliti dengan berbagai tahapan antara lain; studi pustaka, observasi dan wawancara dengan guru MTs Nurul Huda Munjul khususnya guru matematika yang mengajar di kelas VII. Analisis yang dilakukan peneliti adalah analisis kurikulum, analisis peserta didik, analisis materi pada bahan ajar dan analisis muatan nilai-nilai Islam. Dalam pengembangan bahan ajar ini, peneliti merancang dan menetapkan kompetensi inti, kompetensi dasar, dan tujuan pembelajaran sesuai dengan kurikulum yang diterapkan di MTs Nurul Huda Munjul yaitu Kurikulum 2013 sebagai panduan dan ketentuan dalam mengembangkan bahan ajar. Selanjutnya sebagaimana di dalam peneitian ini adalah pengembangan bahan ajar matematika bermuatan nilai-nilai Islam maka dalam penyusunan kompetensi dasar dan tujuan pembelajaran peneliti sesuaikan dengan muatan nilai-nilai Islam.

Hasil analisis yang peneliti peroleh adalah berupa data mengenai aspek dan indikator dalam pengembangan bahan ajar, kesesuaian muatan materi dengan kemampuan peserta didik, kesesuaian materi dengan bahan ajar berbasis multimedia flash, kesesuaian bahan ajar dengan karakteristik peserta didik, dan kesesuaian muatan nilai-nilai Islam dalam bahan ajar yang dikembangkan. Selanjutnya peneliti juga memperoleh data bahwa di madrasah yang menjadi objek penelitian terlihat masih terbatas dalam menerapkan multimedia saat proses pembelajaran, sehingga bahan ajar berbasis multimedia flash interaktif yang dikembangkan ini merupakan jawaban yang diharapkan dapat terus ditingkatkan guna menjadi media pembelajaran yang fundamental di madrasah tersebut saat proses pembelajaran diselenggarakan. 
Berdasarkan analisis kurikulum dan kemampuan peserta didik, peneliti memutuskan untuk menyusun dan mengembangkan bahan ajar matematika dengan muatan materi transformasi berdasarkan pada muatan materi yang terdapat dalam bahan ajar matematika Kurikulum 2013 dari Kementerian Pendidikan dan Kebudayaan. Akan tetapi peneliti memberikan tambahan muatan nilai-nilai Islam pada setiap sub pokok bahasan yang terdapat di dalam bahan ajar. Muatan nilai-nilai Islam yang terdapat dalam bahan ajar ini disesuaikan dengan kemampuan peserta didik baik dari segi isi maupun dari segi bahasa, dan aspek-aspek yang diperhatikan dalam muatan nilai-nilai Islam antara lain; aspek akidah, aspek ibadah dan aspek akhlak. Beberapa muatan nilai Islam dalam aspek akidah adalah penyajian ayat-ayat Al-Qur'an yang berkaitan dengan materi transformasi, hal ini merupakan upaya meningkatkan keimanan peserta didik terhadap Al-Qur'an sebagai pedoman umat Islam, selanjutnya dalam aspek ibadah yaitu peneliti menyajikan pembahasan mengenai penerapan kegiatan ibadah umat Islam yang berkaitan dengan materi transformasi sebagai salah satu upaya penanaman nilai ibadah peserta didik, dan dalam aspek akhlak peneliti menyajikan berbagai kata-kata mutiara penuh hikmah yang mengajak peserta didik untuk semangat beribadah, belajar sungguh-sungguh dan berakhalak mulia.

2. Design (Perancangan)

Dalam tahap perancangan kerangka bahan ajar, peneliti mula-mula menentukan mediamedia yang dapat mendukung pengembangan bahan ajar. Media yang digunakan dalam penelitian dan pengembangan ini adalah media elektronik baik dalam bentuk hardwere maupun softwere. Selanjutnya, pemilihan format yang peneliti tentukan berdasarkan komponen atau kontruktivisme bahan ajar Kurikulum 2013. Format tersebut terdiri atas enam bagian yaitu bagian Kurikulum 2013 yang terdiri dari Kompetensi Inti, Kompetensi Dasar dan Tujuan Pembelajaran, kemudian bagian peta konsep, bagian materi, bagian uji kompetensi, bagian rangkuman dan bagian referensi. Setelah itu, peneliti rangkai alur program bahan ajar atau flowchart. Pada tahap design ini, peneliti juga menyusun kerangka instrumen yang akan digunakan untuk mengetahui kualitas dan efektivitas bahan ajar serta respon siswa terhadap penerapan bahan ajar yang dikembangkan.

3. Development (Pengembangan)

a) Pembuatan bahan ajar dan instrument

Dalam pengembangan bahan ajar, peneliti membuat beberapa video materi ajar terlebih dahulu pada pokok bahasan tranformasi dengan menggunakan aplikasi camtasia studio 8 yang didukung dengan aplikasi-aplikasi lainnya seperti sparkol, powton, power point, geogebra dan paint. Video-video yang dikembangkan memuat beberapa pembahasan materi transformasi seperti pengertian, contoh aplikasi dalam kehidupan sehari-hari, integrasi ayat Al-Qur'an yang berkaitan dengan setiap sub materi pokok bahasan, dan pembahasan keseluruhan materi disertai contoh soal. Pembuatan video materi ajar mengacu pada tahap analisis dan desain yang telah dilakukan. Selanjutnya peneliti menyusun berbagai komponen seperti desain background, animasi, gambar, video, audio, scroll, dan tombol navigasi dengan menggunakan aplikasi macromedia flash professional 8 dengan bantuan berbagai aplikasi yang mendukung pengembangan bahan ajar. Bahan ajar disusun dan dikembangkan berdasarkan rancangan dan ketentuan yang telah dibuat sebelumnya. Instrumen-instrumen yang telah dikembangkan kemudian divalidasi oleh Expert Judgement sampai dinyatakan valid atau layak digunakan.

b) Penilaian atau evaluasi ahli dan guru

Hasil evaluasi bahan ajar oleh ahli materi untuk aspek Isi dan Tujuan adalah 4,1 kemudian untuk aspek instruksional adalah 4,33 dan untuk aspek muatan nilai-nilai Islam adalah 4,07. Sehingga dapat disimpulkan bahwa bahan ajar matematika yang dikembangkan jika dilihat dari segi isi dan tujuan termasuk dalam kategori baik, jika dilihat dari segi intruksional bahan ajar termasuk ke dalam kategori sangat baik, dan jika dilihat dari aspek muatan nilai-nilai Islam maka bahan ajar termasuk ke dalam kategori baik. Hasil evaluasi bahan ajar dari ahli media untuk aspek Teknis adalah 5. Sehingga dapat disimpulkan bahwa bahan ajar matematika yang dikembangkan ini jika dilihat dari segi kualitas teknis, bahan ajar termasuk dalam kategori sangat baik. Adapun nilai yang diperoleh dari hasil evaluasi guru terhadap bahan ajar adalah untuk aspek Isi dan Tujuan memperoleh nilai 4,34 sehingga termasuk ke dalam kategori 
sangat baik, kemudian aspek instruksional memperoleh nilai 4,6 sehingga termasuk kategori sangat baik, aspek muatan nilai-nilai Islam memperoleh nilai 4,33 sehingga termasuk kategori sangat baik, dan untuk aspek teknis memperoleh nilai 4,56 sehingga termasuk kategori sangat baik. Oleh karena itu, dapat disimpulkan bahwa hasil penilaian guru jika dilihat dari segi kuaitas Isi dan tujuan, kualitas instruksional, aspek muatan nilai-nilai Islam dan kualitas teknis, bahan ajar yang telah dikembangkan termasuk ke dalam kategori sangat baik.

Berdasarkan hasil penilaian ahli materi, ahli media, dan guru di atas, maka bahan ajar yang peneliti kembangkan sudah layak digunakan dan diimpementasikan di dalam proses pembelajaran dengan syarat memperbaiki bahan ajar sesuai saran yang diberikan oleh ahli materi, ahli media, dan guru MTs Nurul Huda Munjul.

Setelah bahan ajar direvisi tahap awal sesuai saran dari ahli dan guru, langkah selanjutnya adalah uji coba penerapan bahan ajar dalam proses pembelajaran.

4. Implementation (Penerapan)

penerapan bahan ajar yang telah peneliti kembangkan dilakukan peneliti terhadap siswa kelas VII-B MTs Nurul Huda Munjul yang berjumlah 37 siswa pada bulan Mei 2016. Penerapan bahan ajar saat proses pembelajaran memiliki nuansa religius/islami namun tetap dalam koridor penyamapaian materi transformasi, karena di dalam bahan ajar terdapat muatan nilai-nilai Islam sehingga hal ini menjadikan peserta didik terbawa untuk senantiasa meningkatkan keimanan, ibadah dan akhlak kepada Allah swt. Kemudian bahan ajar yang disajikan berbasis multimedia flash interaktif sehingga dapat mengajak peserta didik tetap semangat dan aktif dalam kegiatan proses pembelajaran. Selanjutnya, Kegiatan pembelajaran dilaksanakan peniliti bukan hanya pada kelas eksperimen melainkan juga kelas kontrol yaitu kelas yang di dalam proses pembelajarnnya tidak menerapkan bahan ajar yang dikembangkan. Kelas kontrol ini adalah kelas VII-E yang berjumlah 37 siswa.

Hasil tes belajar siswa dari kelas eksperimen dan kelas kontrol serta hasil pengisian angket respon siswa dari kelas eksperimen kemudian peneliti analisis untuk mengambil kesimpulan hasil pengembangan bahan ajar matematika bermuatan nilai-nilai Islam yang dikembangkan dengan aplikasi macromedia flash dan camtasia.

5. Evaluation (Evaluasi)

Tahap evaluasi adalah proses untuk menganalisis data yang diperoleh setelah uji coba bahan ajar dalam proses pembelajaran serta tahap untuk melakukan revisi terakhir berdasarkan evaluasi yang dilakukan peneliti dan evaluasi hasil observasi dari guru matematika.

a) Analisis angket respon siswa

Tabel 1

Hasil Angket Respon Siswa

\begin{tabular}{|l|c|c|}
\hline \multicolumn{1}{|c|}{ Aspek } & Nilai Rata-Rata & Kategori \\
\hline Kualitas pembelajaran dan instruksional & 3,91 & Baik \\
\hline Tampilan dan teknis & 3,97 & Baik \\
\hline Integrasi muatan nilai-nilai Islam dalam bahan ajar & 4,05 & Baik \\
\hline Rata-rata total & 3,98 & Baik \\
\hline
\end{tabular}

Berdasarkan tabel diatas, setiap aspek dalam angket respon siswa memiliki kategori baik. Sehingga peneliti dapat menarik kesimpulan bahwa bahan ajar matematika yang peneliti kembangkan mendapat respon yang baik dari para peserta didik, berdasarkan aspek kualitas pembelajaran dan intruksional, aspek tampilan dan teknis, dan aspek integrasi muatan nilai-nilai Islam dengan materi pada bahan ajar yang peneliti kembangkan termasuk layak dan efektif untuk digunakan pada ruang lingkup yang lebih luas.

b) Analisis tes hasil belajar siswa

Berdasarkan ketuntasan belajar individu dan rata-rata hasil evaluasi tes, peserta didik dapat dikatakan tuntas atau lulus apabila nilai rata-rata peserta didik di atas nilai KKM yaitu sebesar 75 dan setidak-tidaknya dari 37 siswa terdapat 32 siswa yang tuntas diatas nilai KKM. Rata-rata nilai hasil tes peserta didik kelas eksperimen adalah $82,34 \geq 75$ artinya rata-rata nilai kelas eksperimen telah tuntas. Kemudian dari 37 
siswa di kelas eksperimen terdapat 33 siswa dinyatakan lulus karena nilai yang diperoleh $\geq$ KKM (75). Adapun rata-rata nilai hasil tes peserta didik kelas kontrol adalah $78,56 \geq 75$ artinya rata-rata nilai kelas kontrol telah tuntas. Akan tetapi dari 37 siswa kelas kontrol hanya 28 siswa dinyatakan lulus karena nilai yang diperoleh $\geq$ KKM (75). Selanjutnya berdasarkan ketuntasan belajar klasikal, peserta didik dinyatakan tuntas apabila nilai klasikal kelas uji coba diatas nilai $85 \%$. Hasil evaluasi tes hasil belajar yang telah dilakukan nilai rata-rata yang diperoleh kelas eksperimen adalah 82,34 dengan ketuntasan secara klasikal sebesar 89,19\% $>85 \%$. Adapun nilai rata-rata yang diperoleh peserta didik dikelas kontrol adalah 78,56 dengan ketuntasan secara klasikal sebesar $75,68 \%<85 \%$. Berdasarkan ketiga kriteria keefektifan yang telah peneliti tentukan yaitu ketuntasan belajar individu, ketuntasan belajar klasikal, dan rata-rata hasil belajar $\geq$ KKM. Masing-masing kriteria untuk kelas eksperimen telah mencapai ketuntasan sehingga dapat dikatakan bahwa penerapan bahan ajar matematika bermuatan nilai-nilai islam yang telah peneliti kembangkan dengan menggunakan aplikasi macromedia flash dan camtasia merupakan efektif terhadap hasil belajar peserta didik.

c) Analisis perbedaan nilai tes hasil belajar siswa kelas ekperimen dan kelas kontrol

1) Uji Normalitas data dilakukan peneliti dengan menggunakan bantuan SPPS versi 20.0 for windows dengan menggunakan uji Kolmogorov-smirnov dengan taraf signifikansi 5\%. Hasil analisis uji normalitas Kolmogorov-Smirnov dari data hasil tes belajar siswa diperoleh nilai normalitas pada kelas eksperimen dan kelas kontrol memiliki nilai 0,000 lebih kecil dari 0,05 sehingga, sebaran data untuk kelas eksperimen dan kelas kontrol tidak berdistribusi normal.

2) Uji Homogenitas dua varians dilakukan pada hasil nilai tes belajar siswa kelas eksperimen dan kelas kontrol dengan menggunakan uji levenetest dengan taraf signifikan 5\%. Setelah dilakukan uji diperoleh nilai signifikansi (sig) yaitu 0,368 yang berarti nilai tersebut lebih besar dari 0,05 . Berdasarkan kriteria pengambilan keputusan maka $\mathrm{H}_{0}$ diterima artinya bahwa kedua kelas tersebut memiliki varians yang sama atau dengan kata lain kedua kelas berasal dari populasi yang variansnya homogen.

3) Uji Hipotesis kesamaan dua rata-rata nilai tes hasil belajar siswa dilakukan dengan melihat hasil uji normalitas dan homogenitas. Oleh karena nilai kedua kelas tidak berdistribusi normal dan keduanya homogen maka peneliti melakukan uji perbedaan dua rata-rata dengan menggunakan uji non parametrik yaitu uji Mann Whitney $U$. Pengujian perbedaan dua rata-rata ini dilakukan dengan menggunakan bantuan software SPSS versi 20 for windows dengan mengambil taraf signifikansi sebesar 0,05 .

Berdasarkan hasil uji Mann Whitney $U$ nilai z hitung yang diperoleh adalah sebesar 1,732. Kemudian, nilai output diperoleh Asymp.Sig (2-Tailed) sebesar 0,083. Pengujian yang dilakukan peneliti adalah uji pihak kiri, maka nilai;

P-Value $=\frac{1}{2} \times$ Asymp.Sig $(2$-tailed $)=\frac{1}{2} \times 0,083=0,0415$.

Nilai tersebut diatas lebih besar dari $\frac{1}{2} \alpha=0,025$, sehingga $\mathrm{H}_{0}$ diterima. Artinya pada taraf kepercayaan $95 \%$ nilai rata-rata peningkatan hasil belajar matematika siswa dengan menerapkan bahan ajar matematika bermuatan nilai-nilai Islam yang peneliti kembangkan lebih tinggi atau sama dengan nilai rata-rata peningkatan hasil belajar matematika siswa yang tidak menerapkan bahan ajar matematika yang peneliti kembangkan.

b. Pembahasan

Bahan ajar matematika bermuatan nilai-nilai Islam yang dikembangkan dengan aplikasi macromedia flash dan camtasia merupakan bahan ajar berbasis multimedia flash interaktif yang dikembangkan dalam bentuk aplikasi komputer. Bahan ajar ini memiliki desain sajian materi yang didukung dengan video, musik, gambar dan animasi yang bertujuan untuk mempermudah dan meningkatkan minat peserta didik dalam mempelajari materi transformasi. Selain itu, bahan ajar ini menyajikan materi transformasi yang dilengkapi dengan komponen-komponen muatan nilai-nilai Islam berupa diantaranya video yang ditampilkan pada awal tiap sub materi pembelajaran yang berisi korespondensi ayat-ayat Al- 
Qur'an dengan materi pokok bahasan dan diikuti dengan pembuktian-pembuktian kemukjizatan Al-Qur'an yang telah Allah swt sampaikan di dalam firman-Nya semisal membahas sebuah fenomena alam semesta jauh sebelum sains membuktikannya. Kemudian pada beberapa tampilan pembahasan pada bahan ajar terdapat pula kata-kata mutiara dan diakhir tiap sub pokok bahasan terdapat ayat-ayat Al-Qur'an dan hadits nabi yang bertujuan untuk membangun semangat keilmuan, penanaman nilai akidah, nilai ibadah dan nilai akhlak tiap peserta didik. Selanjutnya di tiap sub pokok bahasan pada bahan ajar terdapat juga video materi ajar yang dikaitkan dengan muatan nilai-nilai Islam dan aplikasi dalam kehidupan umat Islam. Beberapa muatan nilai-nilai Islam ini sebagai salah satu upaya penanaman nilai-nilai Islam pada diri tiap peserta didik pada saat mereka mempelajari materi pokok bahasan transformasi meskipun ini notabenenya adalah materi mata pelajaran umum.

Langkah yang dilakukan dalam peneltian dan pengembangan ini adalah mengacu pada langkah model ADDIE yang terdiri atas ima langkah yaitu analisis (analysis), perancangan (design), pengembangan (development), implementasi (implementation), dan evaluasi (evaluation). Kelima langkah ini dilakukan untuk menghasilkan bahan ajar matematika bermuatan nilai-nilai Islam berbasis multimedia flash interaktif untuk tingkat SMP/MTs kelas VII pada pokok bahasan transformasi dengan kualitas bahan ajar yang baik.

Hasil penilaian ahli yang terdiri dari ahli materi dan ahli media diperoleh sebuah penilaian bahan ajar sebagai berikut:

Tabel 2

Rata-rata Hasil Penilaian Ahli Materi dan Ahli Media

\begin{tabular}{|c|l|c|c|}
\hline No. & \multicolumn{1}{|c|}{ Aspek } & $\begin{array}{c}\text { Nilai Rata- } \\
\text { Rata }\end{array}$ & Kategori \\
\hline 1. & Kualitas Isi dan Tujuan & 4,1 & Baik \\
\hline 2. & Kualitas Instruksional Bahan Ajar & 4,33 & Sangat Baik \\
\hline 3. & Muatan nilai-nilai Islam & 4,07 & Baik \\
\hline 4. & Kualitas Teknis & 5 & Sangat Baik \\
\hline \multicolumn{2}{|c|}{ Nilai rata-rata } & 4,37 & Sangat Baik \\
\hline
\end{tabular}

Tabel di atas menunukkan bahwa keempat aspek yang digunakan dalam mengevaluasi bahan ajar telah memenuhi kriteria yaitu untuk dua aspek termasuk dalam kategori sangat baik dan dua lainnya termasuk kategori baik. Hal ini dapat ditarik kesimpulan bahwa bahan ajar yang dikembangkan termasuk dalam kategori baik berdasarkan penilaian ahli materi dan ahli media. Adapun hasil penilaian guru MTs Nurul Huda Munjul terhadap bahan ajar dapat dilahat sebagai berikut:

Tabel 3

Rata-rata Hasil Penilaian Guru MTs Nurul Huda Munjul

\begin{tabular}{|c|l|c|c|}
\hline No. & \multicolumn{1}{|c|}{ Aspek } & $\begin{array}{c}\text { Nilai Rata- } \\
\text { Rata }\end{array}$ & Kategori \\
\hline 1. & Kualitas Isi dan Tujuan & 4,34 & Sangat Baik \\
\hline 2. & Kualitas Instruksional Bahan Ajar & 4,6 & Sangat Baik \\
\hline 3. & Muatan nilai-nilai Islam & 4,33 & Sangat Baik \\
\hline 4. & Kualitas Teknis & 4,56 & Sangat Baik \\
\hline \multicolumn{2}{|c|}{ Nilai rata-rata } & 4,46 & Sangat Baik \\
\hline
\end{tabular}

Tabel di atas menunjukkan bahwa bahan ajar yang telah dikembangkan jika dilihat berdasarkan hasil penilaian guru MTs Nurul Huda Munjul memiliki nilai kategori kualitas bahan ajar yang sangat baik. Setelah bahan ajar dievaluasi dan bahan ajar telah selesai dilakukan revisi awal berdasarkan komentar dan saran yang diberikan ahli materi, ahli media dan guru, selanjutnya peneliti melakukan implementasi bahan ajar bahan ajar sebagaimana dibahas pada langkah berikutnya.

Hasil pengisian angket respon siswa diperoleh rata-rata nilai total 3,98 yang merupakan kategori baik sehingga layak digunakan dalam proses pembelajaran. Adapun penilaian masing-masing aspeknya adalah untuk aspek kualitas pembelajaran dan intruksional memperoleh nilai rata-rata 3,91 yang berarti kategori baik, untuk aspek tampilan teknis adalah 3,97 yang merupakan kategori baik dan aspek integrasi muatan nilai-nilai Islam dalam bahan ajar memiliki nilai rata-rata 4,05 yang berarti kategori baik. Penentuan kualitas 
kategori pada nilai ini dilakukan dengan mengacu pada tabel 3.7 yaitu tabel kriteria dan pedoman mengubah data kuantitatif menjadi kualitatif pada angket respon siswa. Selanjutnya berdasarkan hasil tes belajar siswa kelas VII-B diperoleh nilai rata-rata 82,34 dengan ketuntasan secara klasikal sebesar $89,19 \%$ dan dari 37 siswa dinyatakan bahwa 33 siswa telah tuntas secara individual. Hal ini menggambarkan bahwa berdasarkan ketuntasan individual, ketuntasan secara klasikal, dan hasil tes nilai rata-rata siswa bahan ajar yang telah dikembangkan termasuk ke dalam kategori layak atau tuntas untuk dapat diterapkan dalam proses pembelajaran.

Bahan ajar matematika bermuatan nilai-nilai Islam berbasis multimedia flash memiliki komponen-komponen yang telah disusun dan dimuat ke dalam bahan ajar sebagai salah satu upaya untuk memudahkan kegiatan pembelajaran, diantaranya memuat; kompetensi inti, kompetensi dasar, tujuan pembelajaran, petunjuk penggunaan bahan ajar, peta konsep materi, uraian isi materi, gambar/ illustrasi, animasi, dan video untuk memperjelas isi materi, contoh soal, rangkuman, evaluasi, kunci jawaban, dan referensi. Berikut ini pembahasan secara garis besar tampilan komponen-komponen bahan ajar yang telah dikembangkan dalam penelitian ini:

1. Intro: Menyajikan animasi loading dengan tampilan lambang IAIN Syekh Nurjati Cirebon dan setelah itu menampilkan sebuah video intro untuk menuju menu utama yang menapilkan sebuah judul materi bahan ajar dan disertai nama serta nim mahasiswa sebagai pengembang bahan ajar.

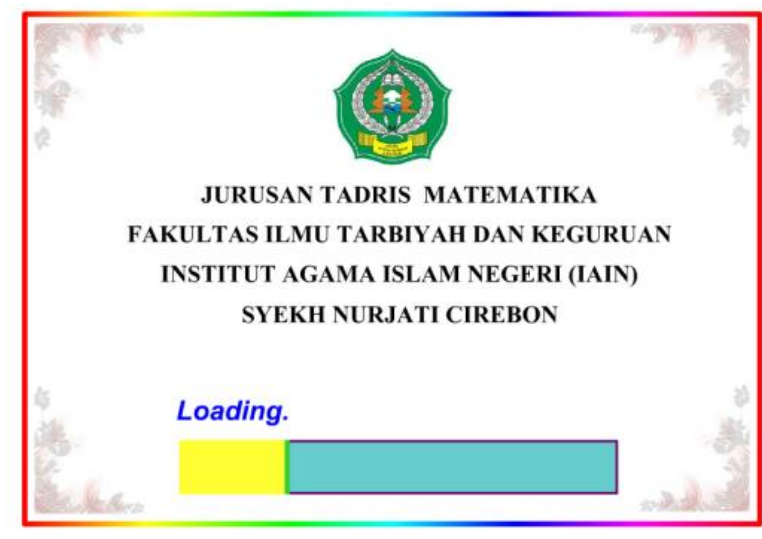

Gambar 1

Intro Bahan Ajar

2. Menu Utama: Menampilkan judul materi bahan ajar yaitu Transformasi untuk tingkat SMP/MTs Kelas VII. Kemudiaan dalam tampilan ini merupakan penghubung ke semua poin dalam bahan ajar yaitu meliputi; K.2013, peta konsep, materi, uji kompetensi, rangkuman, referensi, petunjuk penggunaaan bahan ajar, dan profil penembang.

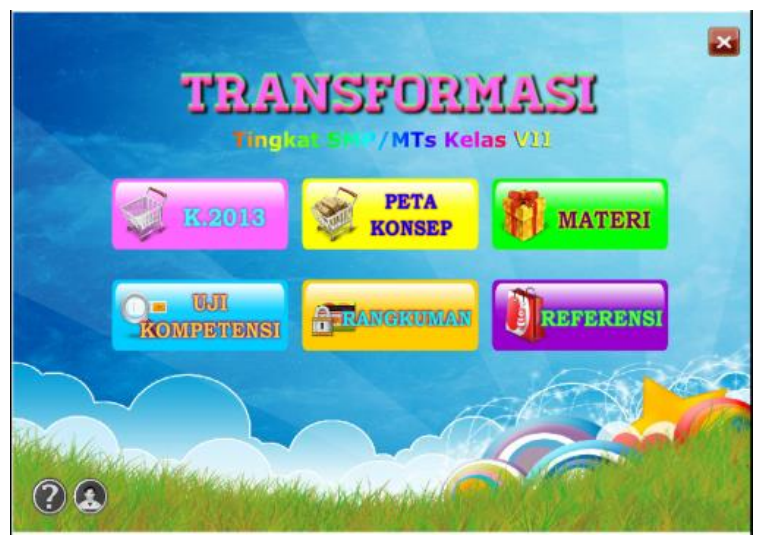

Gambar 2

Menu Utama Materi Transformasi 
3. K.2013 (Kurikulum 2013): Menyajikan tampilan kompetensi inti, kompetensi dasar, dan tujuan pembelajaran yang diterapkan pada bahan ajar ini. Pengembangan bahan ajar ini berdasarkan penerapan pada Kurikulum 2013 dengan pemberian muatan nilai-nilai Islam

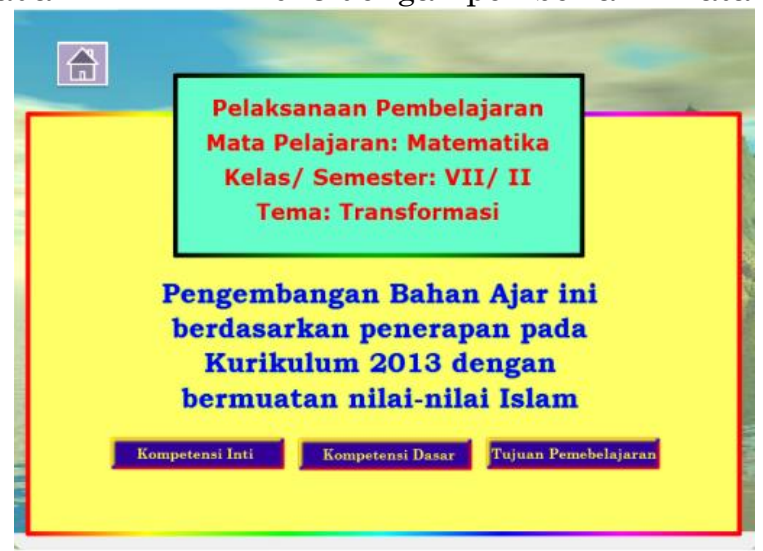

Gambar 3

Kurikulum 2013 pada Bahan Ajar

4. Peta Konsep: Menampilkan peta konsep materi transformasi yang penyajiannya merujuk pada buku paket Kurikulum 2013 dari kementrian pendidikan dan kebudayaan. Pada tampilan ini juga disajikan video peta konsep agar lebih menarik dengan menekan "next" pada tampilan peta konsep.

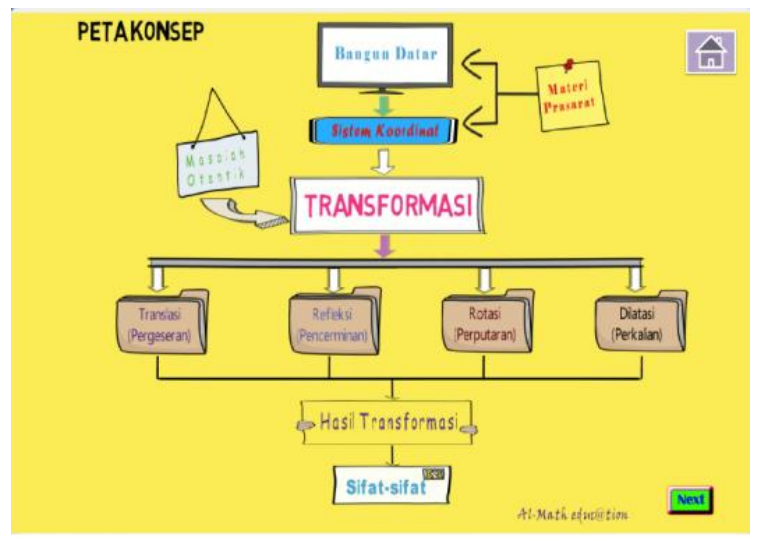

Gambar 4

Peta Konsep Materi Transformasi

5. Materi: Menyajikan materi sub pokok bahasan transformasi yaitu Translasi, Refleksi, Rotasi dan Dilatasi. Pada tiap-tiap sub materi menyajikan pembahasan mula-mula berupa video materi ajar yang berisi tentang pengertian, konsep penerapan dalam kehidupan sehari-hari, dan korespondensi ayat Al-Qur'an yang berkaitan dengan materi pembahasan. Selanjutnya video materi ajar kedua yang menyajikan pembahasan materi. Kemudian pembahasan materi dengan pengembangan macromedia flash, dan selanjutnya rumusrumus, sifat-sifat dan contoh soal materi yang dibahas. Terakhir penyajian video materi ajar yang merupakan video integrasi materi yang dibahas dengan muatan nilai-nilai Islam. 


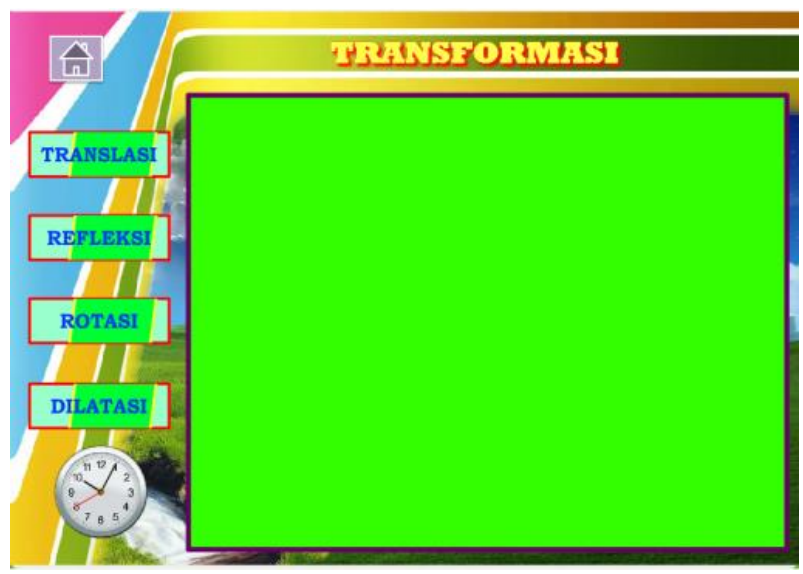

Gambar 5

Sub Materi Transformasi

6. Uji Kompetensi: Menyajikan evaluasi tes tentang materi transformasi untuk peserta didik. Tes ini berisi 30 soal pilihan ganda, peserta didik diminta sebelumnya memasukkan nama, kelas dan jenis kelamin terlebih dahulu sebelum tes dimulai. Setelah tes selesai dilaksankan peserta didik akan langsung mengetahui seberapa banyak soal yang benar dan poin nilai yang diperoleh. Kemudian pengguna bahan ajar ini dapat mengulangi tes dari awal dengan menekan tombol ulang, dan juga bahkan dapat melihat kunci jawaban yang sebenarnya dengan menekan tombol kunci jawaban.

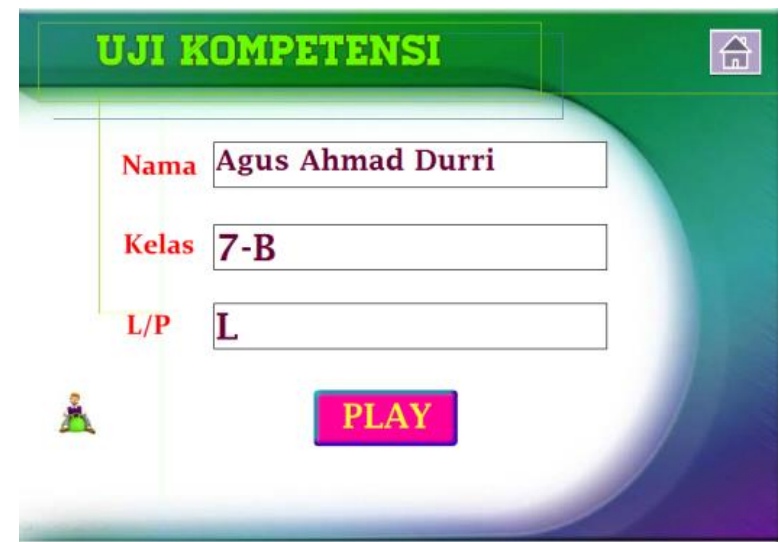

\section{Gambar 6}

Uji Kompetensi Materi Transformasi

7. Rangkuman: Menyajikan rangkuman materi transformasi antara lain terdiri dari translasi, refleksi, rotasi, dan dilatasi. Materi rangkuman yang disajikan hanya berupan pengertian dan rumus-rumus.

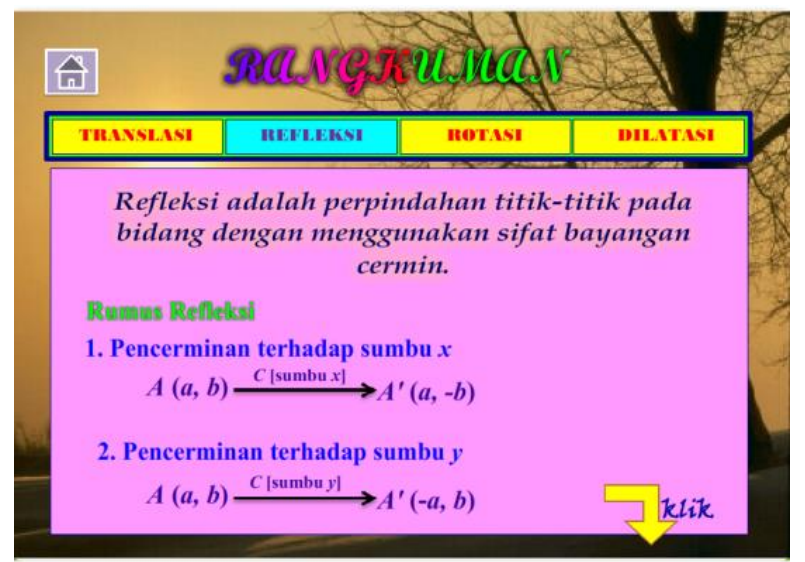

Gambar 7

Rangkuman Materi Transformasi

8. Referensi: Menyajikan daftar pustaka/referensi yang digunakan dalam mengembangkan bahan ajar. 


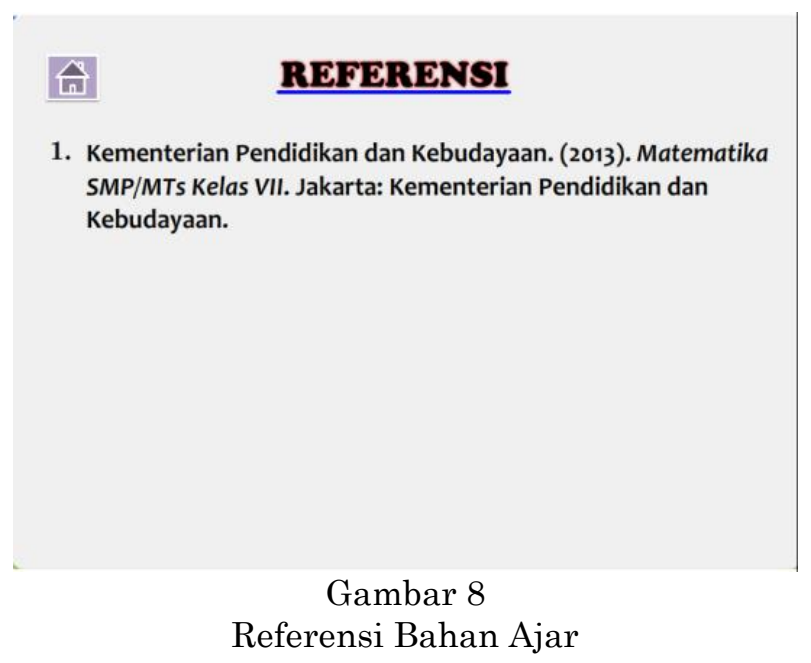

9. Petunjuk Penggunaan Bahan Ajar: Menyajikan petunjuk penggunaan bahan ajar yang meliputi pembahasan tiap-tiap tombol yang digunakan pada bahan ajar, kolom-kolom yang ada pada bahan ajar, dan petunjuk yang harus diikuti pengguna dalam menggunakan bahan ajar.

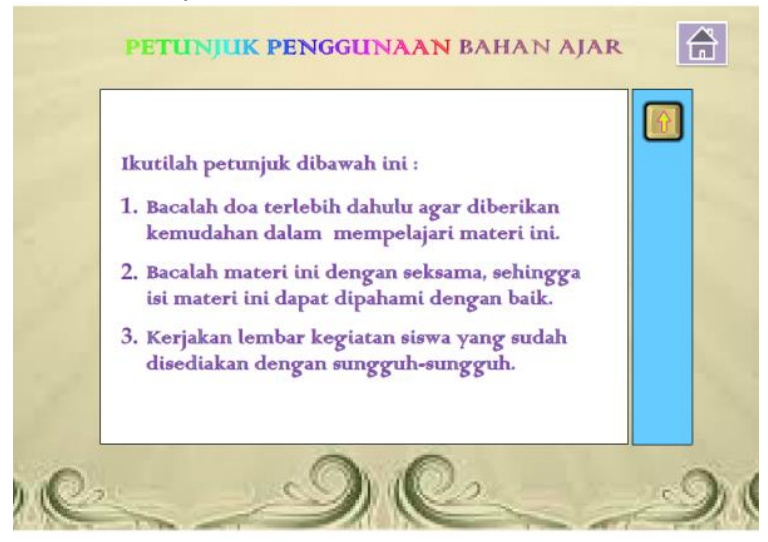

Gambar 9

Sub Materi Transformasi

10. Profil: Menyajikan profil pengembang bahan ajar multimedia flash bermuatan nilai-nilai Islam yang terdiri dari profil mahasiswa yaitu Agus Ahmad Durri, profil dosen pembimbing satu yaitu Bapak Hendri Raharjo, M.Kom dan dosen pembimbing dua yaitu Bapak Arif Muchyidin, M.Si yang telah bersama mengembangkan bahan ajar.

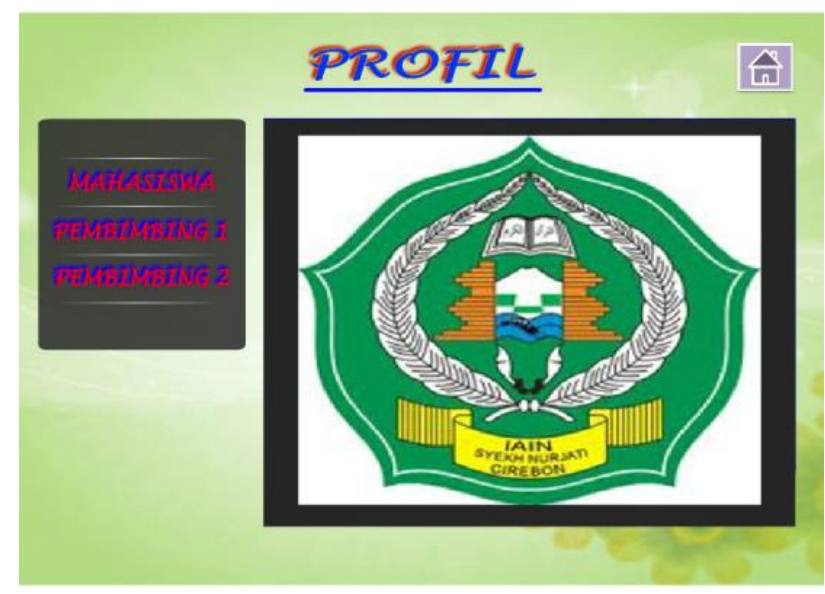

Gambar 10

Profil Pengembang 


\section{KESIMPULAN DAN SARAN}

a. Kesimpulan

Berdasarkan hasil penelitian dan pengembangan yang telah dilakukan oleh peneliti di MTs Nurul Huda Munjul, maka peneliti dapat menarik kesimpulan sebagai berikut:

1. Bahan ajar bermuatan nilai-nilai Islam dalam peneitian ini dikembangkan dengan aplikasi macromedia flash dan camtasia yang didesain dalam bentuk aplikasi komputer. Hasil penilaian angket evaluasi ahli yaitu ahli materi dan ahli media terhadap bahan ajar yang dikembangkan menunjukkan bahwa nilai rata-rata yang diperoleh dari semua aspek yaitu aspek kualitas isi dan tujuan, aspek kualitas instruksional, aspek muatan nilai-nilai Islam, dan aspek kualitas teknis adalah 4,37 dengan kategori sangat baik. Selanjutnya hasil penilaian guru MTs Nurul Huda Munjul terhadap bahan ajar menunjukkan bahwa nilai rata-rata dari setiap aspek adalah 4,46 dengan kategori sangat baik. Sehingga berdarkan penilaian ahli dan guru, bahan ajar matematika berbasis multimedia flash bermuatan nilai-nilai Islam yang dikembangkan dengan macromedia flash dan camtasia layak digunakan dalam proses pembelajaran.

2. Hasil tes evaluasi siswa setelah menggunakan bahan ajar di kelas eksperimen menunjukkan bahwa ketuntasan secara klasikal sebesar $89,19 \%$ artinya siswa yang tuntas/lulus telah mencapai lebih dari $85 \%$, dan nilai rata-rata yang diperoleh peserta didik adalah 82,34 > KKM (75) yang berarti efektif. Berdasarkan data tersebut, dapat peneliti katakan bahwa bahan ajar matematika berbasis multimedia flash bermuatan nilai-nilai Islam efektif digunakan dalam ruang lingkup yang lebih luas.

3. Data hasil angket respon peserta didik terhadap bahan ajar yang dikembangkan menunjukkan bahwa penilaian aspek pembelajaran dan instruksional adalah 3,91 termasuk kategori baik, aspek tampilan dan teknis adalah 3,97 termasuk kategori baik, aspek integrasi muatan nilai-nilai Islam dalam bahan ajar adalah 4,05 termasuk kategori baik. Hasil penilaian angket tersebut menunjukkan bahan ajar termasuk dalam kategori baik dengan rata-rata keseluruhan aspek dan indikator adalah 3,98. Berdasarkan data tersebut disimpulkan bahwa bahan ajar matematika berbasis multimedia flash bermuatan nilai-nilai Islam memiliki dampak positif terhadap respon peserta didik.

4. Hasil tes evaluasi siswa yang dilakukan di kelas eksperimen dan kelas kontrol memiliki perbedaan nilai yang diperoleh. Nilai rata-rata yang diperoleh kelas eksperimen adalah 82,34 lebih besar dari nilai yang diperoleh kelas kontrol yaitu 78,56. Kedua kelas termasuk tuntas karena nilai yang diperoleh masing-masing kelas > KKM (75). Adapun berdasarkan ketuntasan secara klasikal, kelas eksperimen telah memenuhi yaitu sebesar 89,19\% > 85\%, sedangkan kelas kontrol belum memenuhi yaitu sebesar $75,68 \%<85 \%$. Selanjutnya secara statistik, berdasarkan uji hipotesis dengan uji Mann Whitney dengan bantuan Software SPSS versi 20 bahwa terdapat perbedaan nilai rata-rata yang diperoleh kelas eksperimen yaitu lebih besar atau sama dengan nilai rata-rata yang diperoleh kelas kontrol.

b. Saran

Saran-saran yang dapat peneliti sampaikan berdasarkan hasil penelitian dan pengembangan bahan ajar matematika bermuatan nilai-nilai Islam berbasis multimedia interaktif adalah sebagai berikut:

1. Praktis

a) Bagi pendidik hendaknya dapat memanfaatkan bahan ajar ini sebagai salah satu alternatif sumber belajar oleh peserta didik saat proses pembelajaran diselenggarakan dan selama materi yang disajikan didalamnya masih relevan.

b) Bagi pendidik hendaknya memberikan muatan nilai-nilai Islam pada saat proses pembelajaran sebagai salah satu upaya meningkatkan nilai-nilai akidah, ibadah dan akhlak peserta didik.

c) Pemanfaatan bahan ajar ini dapat menjadi jawaban untuk menerapakan proses pembelajaran berbasis e-learning.

d) Bagi peserta didik dapat memanfaatkan dan menggunakan bahan ajar ini bahkan tanpa perlu pembimbing. Selain itu untuk mengembangkan kemampuan matematika disertai pemahaman nilai-nilai Islam, bahan ajar ini menyediakan pembahasan yang lebih baik.

2. Penelitian lanjutan 
Pada pengembangan bahan ajar selanjutnya, sebaiknya pada materi transformasi diberikan materi prasyarat sebelum peserta didik diajak memahami isi materi transformasi. Kemudian diharapkan dapat mengembangkan bahan ajar yang berorientasi bukan hanya pada materi transformasi melainkan pada pokok bahasan lainnya yang tetap memuat nilai-nilai Islam. Selain itu, uji coba bahan ajar sebaiknya dilakukan bukan pada satu sekolah saja melainkan dapat diselenggarakan penelitian kebeberapa sekolah sehingga tingkat kelayakan bahan ajar yang dikembangkan dapat mewakili untuk populasi yang lebih luas. Selanjutnya bahan ajar yang dikembangkan dalam penelitian ini hanya berupa aplikasi komputer, maka diperlukan pengembangan kedepan agar dapat mengembangkan bahan ajar dalam bentuk aplikasi android agar dapat digunakan oleh pengguna smartphone.

\section{DAFTAR PUSTAKA}

Ariani, Niken dan Dani Haryanto. 2010. Pembelajaran Multimedia di Sekolah. Jakarta: Prestasi Pustaka

Aripin. 2009. Step By Step Membuat Video Tutorial Menggunakan Camtasia Studio. Bandung: Oase Media

Baharuddin. 2012. "Pengembangan Sumber Belajar Berbasis Multimedia Interaktif pada Mata Diklat Memasang Instalasi Penerangan Listrik". Artikel dalam Jurnal Teknologi Pendidikan. Vol. 2 No. 1. Medan: Jurusan Pendidikan Teknik Elektro Universitas Negeri Medan

Daryanto. 2011. Media Pembelajaran. Bandung: PT Sarana Tutorial Nurani

Mulyatiningsih, Endang. 2011. Riset Terapan Bidang Pendidikan dan Teknik. Yogyakarta: UNY Press

Muthahhari, Murtadha. 2005. Konsep pendidikan Islam, Alih Bahasa: M. Baharuddin. Jakarta: Iqra Kurnia Gemilang

Sugiyono. 2009. Metode Penelitian Kuantitatif, Kualitatif dan R\&D. Bandung: Alfabeta

Waryanto, Nur Hadi. 2005. Modul Teknik Pembuatan Media Pembelajaran Interaktif dengan Macromedia Flash. Yogyakarta: Laboratorium Komputer Jurusan Pendidikan Matematika Fakultas Matematika dan Ilmu Pengetahuan Alam Universitas Negeri Yogyakarta 